\title{
The effect of trenbolone acetate with time on the various responses of protein synthesis of the rat
}

\author{
BY B. G. VERNON AND P. J. BUTTERY \\ Department of Applied Biochemistry and Nutrition, University of Nottingham School \\ of Agriculture, Sutton Bonington, Loughborough, Leics.
}

(Received 23 February 1978 - Accepted 18 April 1978)

\begin{abstract}
I. The anabolic agent trenbolone acetate (3-0xo-I $7 \beta$-hydroxy-4,9, I I-oestratriene acetate; TBA) given subcutaneously to female rats increased their growth rate compared with that of the placebo-treated controls.

2. The increased growth rate of the TBA-treated rats was not a consequence of an increased water retention. The TBA-treated rats had a significantly higher $(P<0.01)$ total carcass nitrogen content but the total carcass fat content decreased by a non-significant $(P>0.05) 8.3 \%$.

3. There was evidence of a time-lag in the response of the fractional synthetic rate of certain individual tissues to TBA. The fractional synthetic rates of the uterus and skeletal muscle mixed tissue proteins were significantly reduced in the TBA-treated rats.

4. The measured reduction in fractional synthetic rates was concluded to reflect true changes in the synthetic rate rather than a result of an alteration in the specific activity of the tyrosine pool used for protein synthesis.
\end{abstract}

Anabolic agents are being used to increase the productivity of animals. Their implantation causes an increased rate of protein deposition in the animal. Tissue proteins have been reported to exhibit considerable turnover (see, for example, Schimke \& Doyle, I970; Goldberg \& Dice, 1974), thus regulation of the size of the body-tissue protein pool could be exerted through changes in either protein synthesis or breakdown. It appears likely that the over-all control of the liver protein mass may be exerted through changes in the rate of proteolysis (Garlick, Millward \& James, I973). However, whether regulation of skeletal muscle mass is through protein synthesis or degradation or by a combination of both processes is not totally clear. Protein synthesis would appear to be a primary regulation site since muscle synthesis is very sensitive to dietary changes (Waterlow \& Stephen, 1968; Millward, Garlick, Nnanyelugo \& Waterlow, 1976). However, regulatory changes in the rate of muscle breakdown have been reported (Goldberg, 1969a, $b$; Millward, Garlick, Stewart, Nnanyelugo \& Waterlow, 1975). Protein synthesis and degradation (turnover) can be controlled by peptide hormones (Manchester, 1976), steroid hormones (Goldberg, Howell, Li, Martel \& Prouty, 1974) and amino acid supply (Clemens \& Pain, 1976). It has been proposed that changes in the plasma insulin and growth hormone concentration of ruminants after oestrogen administration may be the key to the observed anabolic effect on protein metabolism (Preston, 1975). Both growth hormone and insulin have been reported to increase the rate of protein synthesis (Mueller, 1974) and insulin to decrease the rate of protein degradation (Goldberg et cil. 1974); changes conducive to promoting an increase in growth rate.

We have reported previously that the anabolic agent trenbolone acetate (3-oxo- 7 hydroxy-4,9, I I-oestratriene acetate; TBA) increased the growth rate of treated female rats by a decrease in both protein synthesis and degradation (Vernon \& Buttery, 1976). In addition, TBA-treated female rats exhibited a significant reduction in myofibrillar catabolism (determined from total urinary $N^{t}$-methylhistidine excretion) within $3 \mathrm{~d}$ of commencement of treatment and this reduction was maintained throughout the experimental period (Vernon \& Buttery, 1978). In this paper we have examined the effect of TBA with time on 
aspects of protein metabolism. In addition, the effect of TBA on water retention was examined since in certain instances the therapeutic application of androgens and anabolic agents is accompanied by oedema (Kruskemper, 1968). It is assumed that TBA in rat plasma is deacetylated to the apparently active component trenbolone (3-oxo-1 $7 \beta$-hydroxy4,9, I I-oestratriene) (Pottier, Busigny \& Grandadam, 1975).

\section{MATERIAL AND METHODS}

\section{Animal and diets}

Specific-pathogen-free Wistar female rats (Joint Animal Breeding Unit, Nottingham University) were used. They were randomly distributed to individual metabolism cages and allowed access to food and water $a d$ lib. A $12 \mathrm{~h}$ light-dark cycle was employed.

Rats were evenly divided into groups. One group was injected with a placebo and the other group received TBA $(800 \mu \mathrm{g} / \mathrm{kg}$ body-weight). Both groups of rats were injected daily via the neck skin fold. Preparation of the placebo and TBA injections followed that described by Vernon \& Buttery (I976).

\section{Expt 1. Tissue fractional synthetic rates}

The fractional synthetic rates of mixed tissue proteins were determined by the constantinfusion method, including the method of calculation, described by Waterlow \& Stephen (I968) using L-[U- $\left.{ }^{14} \mathrm{C}\right]$ tyrosine (Vernon \& Buttery, 1976). On days 1,7 and 14 after commencement of TBA treatment, rats (six/group) were infused with $\mathrm{L}-\left[\mathrm{U}-{ }^{14} \mathrm{C}\right]$ tyrosine (The Radiochemical Centre, Amersham, Bucks.), diluted to $2 \mu \mathrm{Ci} / \mathrm{ml}$ saline ( 9 g sodium chloride/ 1) (specific activity $10 \mathrm{mCi} / \mathrm{mmol}$ ), into a tail vein at a rate of $0.64 \mathrm{ml} / \mathrm{h}$ for $6 \mathrm{~h}$. At the end of the infusion rats were killed by cervical dislocation, tissues frozen in liquid nitrogen and stored at $-20^{\circ}$ until analysed. The determination of tissue protein-bound and intracellular free tyrosine specific activities after precipitation of protein with trichloroacetic acid ( $100 \mathrm{~g} / \mathrm{l})$ and picric acid ( $\mathrm{I} 0 \mathrm{~g} / \mathrm{l})$, respectively, followed that described by Vernon \& Buttery (1976). Plasma free tryosine specific activity was determined as described for tissue intracellular samples after deproteinization by the method of Stein \& Moore (I954).

The skeletal muscle protein content was measured by the procedure of Lowry, Rosebrough, Farr \& Randall (I95I) and the RNA content by reaction with orcinol (Kerr \& Seraidorian, 1945) following tissue preparation as described by Munro \& Fleck (1969). The skeletal muscle DNA content was measured by reaction with diphenylamine (Burton, 1956) after acid-hydrolysis ( $0.8 \mathrm{M}$-perchloric acid at $90^{\circ}$ for $15 \mathrm{~min}$ ) of the precipitate obtained from the RNA extraction procedure described previously.

The amount of skeletal muscle protein synthesized ( $\mathrm{g} / \mathrm{d}$ per $\mathrm{g}$ RNA) was determined by dividing the fractional synthetic rate by RNA : protein. This term has been defined as the activity of RNA (Millward et al. 1975).

Determination of the concentrations of plasma and skeletal muscle intracellular free amino acids was based on the separation system devised by Atkin \& Ferdinand (1970) for physiological fluids, using an amino acid analyser (Locarte Co., London). The skeletal muscle intracellular free amino acid concentration was corrected for extracellular contamination from the inulin results determined in Expt 2. 
Table $\mathrm{I}$. The effect of trenbolone acetate $(T B A)$ on weight gain of the entire female rat

(Mean values with their standard errors for six observations for Expts 1 and 3 and for three observations for Expt 2)

\begin{tabular}{|c|c|c|c|c|c|c|c|c|}
\hline \multirow{2}{*}{$\begin{array}{c}\text { Expt } \\
\text { no. }\end{array}$} & \multirow[b]{2}{*}{ Day } & \multirow[b]{2}{*}{ Treatment } & \multicolumn{2}{|c|}{ Initial wt $(\mathrm{g})$} & \multicolumn{2}{|c|}{ Final wt $(g)$} & \multicolumn{2}{|c|}{ Wt gain (g) } \\
\hline & & & Mean & $\mathrm{SE}$ & Mean & $\mathrm{SE}$ & Mean & SE \\
\hline \multirow[t]{4}{*}{ I } & I & Con & II 6 & $2 \cdot 29$ & II9.I & I.56 & $2 \cdot 7$ & 0.56 \\
\hline & & $T B$ & 119 & $I \cdot 24$ & 123.9 & I. 42 & 47 & $0.59^{*}$ \\
\hline & 7 & $\begin{array}{l}\text { Control } \\
\text { TBA }\end{array}$ & $\begin{array}{l}121 \cdot 3 \\
\text { II } 9 \cdot 1\end{array}$ & $\begin{array}{l}3 \cdot 41 \\
3 \cdot 13\end{array}$ & $\begin{array}{l}129.0 \\
140.5\end{array}$ & $\begin{array}{l}3.08 \\
5.23\end{array}$ & $\begin{array}{r}7 \cdot 7 \\
21.4\end{array}$ & $\begin{array}{l}0 \cdot 76 \\
2 \cdot 39^{* * *}\end{array}$ \\
\hline & I4 & $\begin{array}{l}\text { Control } \\
\text { TBA }\end{array}$ & $\begin{array}{l}117.9 \\
117.6\end{array}$ & $\begin{array}{l}1.63 \\
2.04\end{array}$ & $\begin{array}{l}\text { I } 42 \cdot I \\
\text { I } 66 \cdot 9\end{array}$ & $\begin{array}{l}2 \cdot 78 \\
5 \cdot 5^{* * *}\end{array}$ & $\begin{array}{l}24 \cdot 2 \\
49 \cdot 3\end{array}$ & $\begin{array}{l}I \cdot 66 \\
4 \cdot 29^{* * *}\end{array}$ \\
\hline \multirow[t]{2}{*}{2} & 7 & $\begin{array}{l}\text { Control } \\
\text { TBA }\end{array}$ & $\begin{array}{l}117 \cdot 6 \\
116 \cdot 3\end{array}$ & $\begin{array}{l}3.54 \\
\mathrm{I} \cdot 42\end{array}$ & $\begin{array}{r}130.3 \\
138.6\end{array}$ & $\begin{array}{l}2 \cdot 53 \\
\text { I. } 49^{*}\end{array}$ & $\begin{array}{l}\text { I } 2 \cdot 7 \\
22 \cdot 3\end{array}$ & $\begin{array}{l}0.70 \\
0.98^{* * *}\end{array}$ \\
\hline & I4 & $\begin{array}{l}\text { Control } \\
\text { TBA }\end{array}$ & $\begin{array}{l}78 \cdot 0 \\
76 \cdot 6\end{array}$ & $\begin{array}{l}1.64 \\
2.04\end{array}$ & $\begin{array}{l}103.2 \\
124.9\end{array}$ & $\begin{array}{l}2 \cdot 78 \\
5 \cdot 31\end{array}$ & $\begin{array}{l}25 \cdot 2 \\
48 \cdot 3\end{array}$ & $\begin{array}{l}I \cdot 66 \\
4 \cdot 29^{* * *}\end{array}$ \\
\hline 3 & 14 & $\begin{array}{l}\text { Control } \\
\text { TBA }\end{array}$ & $\begin{array}{l}106.9 \\
105.9\end{array}$ & $\begin{array}{l}0.72 \\
0.46\end{array}$ & $\begin{array}{r}132.9 \\
147.7\end{array}$ & $\begin{array}{l}1 \cdot 44 \\
\mathrm{I} \cdot 68^{* * *}\end{array}$ & $\begin{array}{l}26 \cdot 0 \\
41 \cdot 0\end{array}$ & $\begin{array}{l}\mathrm{I} \cdot 4 \mathrm{I} \\
\mathrm{I} \cdot 36^{* * *}\end{array}$ \\
\hline
\end{tabular}

Statistical significance of differences between treatments: ${ }^{*} P<0.05,{ }^{* * *} P<0.001$.

\section{Expt 2. Individual tissue water content}

Rats (three/group) were maintained and injected for 7 and $14 \mathrm{~d}$ before the following procedures. A lateral tail vein was cannulated and I $\mu \mathrm{Ci}\left[{ }^{3} \mathrm{H}\right]$ inulin (specific activity $860 \mathrm{mCi} / \mathrm{mmol}$; The Radiochemical Centre, Amersham, Bucks.) in $0.1 \mathrm{ml}$ saline was injected into the vein. The tail was sealed to prevent leakage. After $4 \mathrm{~h}$ blood was obtained using heart puncture. Plasma and individual tissues were frozen in liquid $\mathrm{N}$ and stored at $-20^{\circ}$ until analysed. Plasma was deproteinized by mixing thoroughly equal volumes of plasma and sulphosalicylic acid solution $(60 \mathrm{~g} / \mathrm{l})$. Tissue intracellular samples were prepared for analysis by the picric acid method described Vernon \& Buttery (1976). The extracellular tissue water content ( $\mathrm{ml} / \mathrm{g}$ wet weight) of a tissue sample was determined by comparison of the radioactive inulin present in the tissue with that found in the plasma. Total tissue water content was determined by drying approximately I $g$ of the tissue to constant weight in a vacuum oven at $90^{\circ}$.

\section{Expt 3. Carcass water, nitrogen and fat content}

Rats (six/group) were maintained and injected for $14 \mathrm{~d}$ before the determination of carcass water, $\mathrm{N}$ and fat content. Total body water content was determined by drying the carcass to constant weight in a vacuum oven at $90^{\circ}$. Before drying, an incision was made through the loose skin and abdominal wall extending from the xiphoid process to the pubic symphysis. The skin and abdominal wall were reflected either side of the mid-line incision. Finally, the diaphragm was cut away from the ribs. Total body fat (light petroleum (b.p. $40-60^{\circ}$ ) extraction) and $\mathrm{N}$ content were determined as laid down by the Association of Official Agricultural Chemists (1970).

\section{Statistical analysis}

Results are expressed as mean values with their standard errors and were analysed according to Student's $t$ test. Non-significance in statistical analysis was assumed to occur at $P>0.05$. 
Table 2. Expt 2. The effect of trenbolone acetate (TBA) on tissue weights $(\%$ final body weight $)$ of the entire female rat

(Mean values with their standard errors for six observations)

\begin{tabular}{|c|c|c|c|c|c|c|c|}
\hline \multirow[b]{2}{*}{ Day } & \multirow[b]{2}{*}{ Treatment } & \multicolumn{2}{|c|}{ Liver } & \multicolumn{2}{|c|}{ Uterus } & \multicolumn{2}{|c|}{ Heart } \\
\hline & & Mean & SE & Mean & SE & Mean & SE \\
\hline I & $\begin{array}{l}\text { Control } \\
\text { TBA }\end{array}$ & & & $\begin{array}{l}0.16 \\
0.14\end{array}$ & $\begin{array}{l}0.017 \\
0.008\end{array}$ & $\begin{array}{l}0.48 \\
0.48\end{array}$ & \\
\hline 7 & $\begin{array}{l}\text { Control } \\
\text { TBA }\end{array}$ & & $\begin{array}{l}0.08 \\
0.117\end{array}$ & $\begin{array}{l}0.18 \\
0.19\end{array}$ & $\begin{array}{l}0.013 \\
0.013\end{array}$ & $\begin{array}{l}0.46 \\
0.47\end{array}$ & $\begin{array}{l}0.018 \\
0.009\end{array}$ \\
\hline 14 & $\begin{array}{l}\text { Control } \\
\text { TBA }\end{array}$ & $\begin{array}{l}3.58 \\
3.42\end{array}$ & $\begin{array}{l}0.113 \\
0.059\end{array}$ & $\begin{array}{l}0.18 \\
0.16\end{array}$ & $\begin{array}{l}0.014 \\
0.012\end{array}$ & $\begin{array}{l}0.44 \\
0.42\end{array}$ & $\begin{array}{l}0.012 \\
0.009\end{array}$ \\
\hline
\end{tabular}

Statistical significance of difference between treatments: $* P<0.05$

Table 3. Expt 2. The effect of trenbolone acetate $(T B A)$ on individual tissue extracellular and total water content $(\mathrm{ml} / \mathrm{g}$ wet $\mathrm{wt}$ ) of the entire female rat

(Mean values with their standard errors for three observations. On days 7 and 14 after the commencement of TBA treatment ( $800 \mu \mathrm{g} / \mathrm{kg}$ body-weight per d))

\begin{tabular}{|c|c|c|c|c|c|c|c|c|c|}
\hline \multirow{2}{*}{\multicolumn{2}{|c|}{$\begin{array}{l}\text { Treatment } \ldots \\
\text { Water content }\end{array}$}} & \multicolumn{4}{|c|}{ TBA } & \multicolumn{4}{|c|}{ Control } \\
\hline & & \multicolumn{2}{|c|}{ Total } & \multicolumn{2}{|c|}{ Extracellular } & \multicolumn{2}{|c|}{ Total } & \multicolumn{2}{|c|}{ Extracellular } \\
\hline Day & Tissue & Mean & SE & Mean & SE & Mean & SE & Mean & SE \\
\hline 7 & $\begin{array}{l}\text { Liver } \\
\text { Uterus } \\
\text { Heart } \\
\text { Muscle }\end{array}$ & $\begin{array}{l}0.75 \\
0.79 \\
0.78 \\
0.76\end{array}$ & $\begin{array}{l}0.008 \\
0.006 \\
0.005 \\
0.009\end{array}$ & $\begin{array}{l}0.3 \\
0.25 \\
0.23 \\
0.16\end{array}$ & $\begin{array}{l}0.009 \\
0.006 \\
0.010 \\
0.011\end{array}$ & $\begin{array}{l}0.76 \\
0.79 \\
0.77 \\
0.76\end{array}$ & $\begin{array}{l}0.009 \\
0.010 \\
0.006 \\
0.008\end{array}$ & $\begin{array}{l}0.29 \\
0.26 \\
0.21 \\
0.16\end{array}$ & $\begin{array}{l}0.007 \\
0.008 \\
0.008 \\
0.009\end{array}$ \\
\hline I4 & $\begin{array}{l}\text { Liver } \\
\text { Uterus } \\
\text { Heart } \\
\text { Muscle }\end{array}$ & $\begin{array}{l}0.76 \\
0.79 \\
0.77 \\
0.75\end{array}$ & $\begin{array}{l}0.011 \\
0.008 \\
0.006 \\
0.012\end{array}$ & $\begin{array}{l}0.28 \\
0.22 \\
0.22 \\
0.17\end{array}$ & $\begin{array}{l}0.010 \\
0.006 \\
0.008 \\
0.011\end{array}$ & $\begin{array}{l}0.77 \\
0.80 \\
0.77 \\
0.75\end{array}$ & $\begin{array}{l}0.008 \\
0.011 \\
0.009 \\
0.010\end{array}$ & $\begin{array}{l}0.30 \\
0.24 \\
0.22 \\
0.16\end{array}$ & $\begin{array}{l}0.009 \\
0.011 \\
0.009 \\
0.012\end{array}$ \\
\hline
\end{tabular}

The differences between treatments were not significant: $P>0.05$.

For details, see p. 565 .

\section{RESULTS}

\section{Growth rate and tissue sizes}

The effect of TBA on growth rate in Expts I-3 is recorded in Table I. In Expt I there was a significant growth stimulation I d after commencement of TBA treatment and this increase was maintained throughout the experimental period. These stimulated growth rates confirm previously reported results (Vernon \& Buttery, 1976, 1978) and serves to illustrate that the animals used in the present study were responding to the agent.

The observed increases (Expt 2) in tissue sizes after TBA treatment (Table 2) were not a consequence of an increased water retention (Table 3). Although the total carcass water content was slightly $(2.7 \%)$ but significantly increased $(P<0.00 \mathrm{I})$ in the TBA-treated rats after a $14 \mathrm{~d}$ injection period (Table 4 ), it was assumed that the observed stimulation in growth rate 1,7 and $14 \mathrm{~d}$ after commencement of TBA treatment was not only a consequence of an increased water retention.

The extracellular tissue water content of the placebo-treated controls (Table 3) was 
Table 4. Expt 3. The effect of trenbolone acetate (TBA) on carcass water, nitrogen and fat content

(Mean values with their standard errors for six observations. On day 14 after the commencement of TBA treatment $(800 \mu \mathrm{g} / \mathrm{kg}$ body weight per d) total carcass water, nitrogen and fat (light petroleum (b.p. $40-60^{\circ}$ ) ether extraction) content were determined)

$\begin{array}{lrrrrr}\text { Treatment } \ldots & \overbrace{\text { Mean }} & \text { SE } & \overbrace{\text { Mean }}^{\text {TBA }} & \text { SE } \\ \text { Water (g/kg wet body-wt) } & 646.0 & 2.6 & 629.0 & 3.5^{* * *} \\ \text { Nitrogen }(\mathrm{g} / \mathrm{kg} \text { dry body-wt) } & 83.5 & \mathrm{I} \cdot 09 & 78.3 & \mathrm{I} \cdot 15^{* *} \\ \text { Fat (g/kg dry body-wt) } & 298.0 & 7.03 & 325.0 & \text { I2.8 NS }\end{array}$

NS, Not significant.

Statistical significance of differences between treatments: ${ }^{* *} P<0.01,{ }^{* * *} P<0.001$.

For details, see p. 565 .

Table 5. Expt I. Effect of trenbolone acetate (TBA) on fractional synthetic rate and intracellular: extracellular free tyrosine specific activity of individual tissues in the entire female rat

(Mean values with their standard errors for six observations. On days I, 7 and 14 after commencement of TBA treatment $(800 \mu \mathrm{g} / \mathrm{kg}$ body weight per d) tissue fractional synthetic rates and the intracellular : extracellular free tyrosine specific activities were determined using the continuousinfusion technique)

Tissue $\ldots$

$\begin{aligned} \text { Day } & \text { Treatment } \\ \text { I } & \text { TBA } \\ & \text { Control } \\ 7 & \text { TBA } \\ & \text { Control } \\ \text { I4 } & \text { TBA } \\ & \text { Control }\end{aligned}$

\begin{tabular}{ll}
$\overbrace{\text { Mean }}$ & \multicolumn{1}{c}{ SE } \\
0.103 & 0.0022 \\
0.110 & 0.0026 \\
0.073 & $0.0027^{* * *}$ \\
0.097 & 0.0025 \\
0.074 & $0.0034^{*}$ \\
0.091 & 0.0042
\end{tabular}

\begin{tabular}{llll}
$\overbrace{\text { Mean }}^{c}$ SE & \multicolumn{1}{c}{ Uterus } & Mean & \multicolumn{1}{c}{ SE } \\
0.144 & 0.0141 & 0.44 & 0.037 \\
0.169 & 0.0122 & 0.48 & 0.026 \\
0.126 & 0.0093 & 0.33 & 0.049 \\
0.140 & 0.010 & 0.40 & 0.033 \\
0.125 & 0.0081 & 0.26 & $0.027^{* * *}$ \\
0.130 & 0.011 & 0.51 & 0.019
\end{tabular}

$\begin{array}{cc}\overbrace{\text { Mean }} & \text { SE } \\ 0.80 & 0.045 \\ 0.82 & 0.046 \\ 0.67 & 0.043 \\ 0.73 & 0.044 \\ 0.81 & 0.054 \\ 0.73 & 0.077\end{array}$

Intracellular : extracellular free tyrosine specific activities

\begin{tabular}{|c|c|c|c|c|c|c|c|c|}
\hline $\begin{array}{l}\text { TBA } \\
\text { Control }\end{array}$ & $\begin{array}{l}49 \cdot 9 \\
53 \cdot 5\end{array}$ & $\begin{array}{l}3.95 \\
0.47\end{array}$ & $\begin{array}{l}8 \mathrm{I} \cdot 3 \\
84 \cdot 3\end{array}$ & $\begin{array}{l}6.23 \\
6 \cdot 13\end{array}$ & $\begin{array}{l}42 \cdot 3 \\
46 \cdot 4\end{array}$ & $\begin{array}{l}3 \cdot 18 \\
5 \cdot 45\end{array}$ & $\begin{array}{l}33.2 \\
38 \cdot 4\end{array}$ & $\begin{array}{l}2.41 \\
3.26\end{array}$ \\
\hline $\begin{array}{l}\text { TBA } \\
\text { Control }\end{array}$ & $\begin{array}{l}58 \cdot 5 \\
60 \cdot 1\end{array}$ & $\begin{array}{l}3.19 \\
1.80\end{array}$ & $\begin{array}{l}85.9 \\
77.0\end{array}$ & $\begin{array}{l}4 \cdot 03 \\
4 \cdot 76\end{array}$ & $\begin{array}{l}65 \cdot 2 \\
35 \cdot 5\end{array}$ & $\begin{array}{c}\text { II.2 } \\
8 \cdot 79\end{array}$ & $\begin{array}{l}40 \cdot 3 \\
43.6\end{array}$ & $\begin{array}{l}\text { I.94 } \\
2.98\end{array}$ \\
\hline $\begin{array}{l}\text { TBA } \\
\text { Control }\end{array}$ & $\begin{array}{l}52 \cdot 3 \\
47 \cdot 5\end{array}$ & $\begin{array}{l}2 \cdot 78 \\
2 \cdot 29\end{array}$ & $\begin{array}{l}80.9 \\
86.8\end{array}$ & $\begin{array}{l}5.94 \\
4.40\end{array}$ & $\begin{array}{l}4 I \cdot 4 \\
46 \cdot 9\end{array}$ & $\begin{array}{l}4 \cdot 54 \\
4 \cdot 58\end{array}$ & $\begin{array}{l}30 \cdot 3 \\
35 \cdot 6\end{array}$ & $\begin{array}{l}1 \cdot 13 \\
2 \cdot 00\end{array}$ \\
\hline
\end{tabular}

Statistical significance of differences between treatments: ${ }^{*} P<0.05,{ }^{* * *} P<0.001$. For details, see p. 564.

similar to previously-published results (Scharff \& Wool, I965; Waterlow \& Stephen, 1968; Hider, Fern \& London, I971), except that no published results are available for the uterus.

\section{Expt 3. Carcass $N$ and fat content}

The effect of TBA on the total carcass $\mathrm{N}$ and fat content is recorded in Table 4 . The significant increase $(P<0.001)$ in the total carcass $N$ content of the TBA-injected rats is consistent with the reported more positive $\mathbf{N}$ retention in rats (Vernon \& Buttery, 1978) 
Table 6. Expt $\mathrm{I}$. The effect of trenbolone acetate $(T B A)$ on skeletal muscle $R N A, D N A$ and protein content ( $\mathrm{mg} / \mathrm{g}$ wet weight muscle) and the activity of skeletal muscle $R N A$ ( $g$ protein synthesized/d perg $R N A$ ) of the entire female rats and weight and $R N A$ of untreated entire rats)

\begin{tabular}{|c|c|c|c|c|c|c|c|c|c|}
\hline \multirow[b]{2}{*}{ Day } & \multirow[b]{2}{*}{ Treatment } & \multicolumn{2}{|c|}{ RNA } & \multicolumn{2}{|c|}{ DNA } & \multicolumn{2}{|c|}{ Protein } & \multicolumn{2}{|c|}{ Activity of RNA } \\
\hline & & Mean & SE & Mean & $\mathbf{S E}$ & Mean & SE & Mean & SE \\
\hline $\mathbf{I}$ & $\begin{array}{l}\text { TBA } \\
\text { Control }\end{array}$ & $\begin{array}{l}I \cdot 03 \\
I \cdot 07\end{array}$ & $\begin{array}{l}0.042 \\
0.038\end{array}$ & $\begin{array}{l}0.47 \\
0.46\end{array}$ & $\begin{array}{l}0.011 \\
0.006\end{array}$ & $\begin{array}{l}186.0 \\
185.0\end{array}$ & $\begin{array}{l}I \cdot 9 \\
2 \cdot 0\end{array}$ & $\begin{array}{l}18 \cdot 7 \\
19 \cdot 0\end{array}$ & $\begin{array}{l}0 \cdot 76 \\
I \cdot 21\end{array}$ \\
\hline 7 & $\begin{array}{l}\text { TBA } \\
\text { Control }\end{array}$ & $\begin{array}{l}1.33 \\
1.09\end{array}$ & $\begin{array}{l}0.113 \\
0.077\end{array}$ & $\begin{array}{l}0.51 \\
0.48\end{array}$ & $\begin{array}{l}0.011 \\
0.016\end{array}$ & $\begin{array}{l}187.0 \\
185.0\end{array}$ & $\begin{array}{l}1.99 \\
1 \cdot 0\end{array}$ & $\begin{array}{l}10 \cdot 3 \\
16 \cdot 0\end{array}$ & $\begin{array}{l}0.72^{* * *} \\
1 \cdot 13\end{array}$ \\
\hline \multirow[t]{3}{*}{14} & $\begin{array}{l}\text { TBA } \\
\text { Control }\end{array}$ & $\begin{array}{l}I \cdot 36 \\
I \cdot I 3\end{array}$ & $\begin{array}{l}0.059^{*} \\
0.058\end{array}$ & $\begin{array}{l}0.50 \\
0.49\end{array}$ & $\begin{array}{l}0.006 \\
0.010\end{array}$ & $\begin{array}{l}183.0 \\
183.0\end{array}$ & $\begin{array}{l}2 \cdot 0 \\
2 \cdot 1\end{array}$ & $\begin{array}{l}10 \cdot 0 \\
14.7\end{array}$ & $\begin{array}{l}0.55^{* * *} \\
0.61\end{array}$ \\
\hline & & \multicolumn{8}{|c|}{ Untreated rats } \\
\hline & & & & \multicolumn{2}{|c|}{ Wt $(g)$} & \multicolumn{2}{|c|}{ RNA } & & \\
\hline & $\begin{array}{l}\text { re male } \\
\text { re female }\end{array}$ & & & $\begin{array}{l}66 \cdot 2 \\
64 \cdot 2\end{array}$ & $\begin{array}{l}0.87 \\
1.00\end{array}$ & $\begin{array}{l}\mathrm{I} \cdot 48 \\
0.98\end{array}$ & $\begin{array}{l}0.08 \\
0.0\end{array}$ & $\begin{array}{l}8 \mathrm{I} \\
\mathrm{II}^{* * *}\end{array}$ & \\
\hline
\end{tabular}

Statistical significance of differences between treatments: ${ }^{*} P<0.05,{ }^{* * *} P<0.001$. For details, see p. 564 .

and in cattle (Chan, Heitzman \& Kitchenham, 1975) after TBA treatment. Results consistent with previously published reductions in total carcass fat content following steroid treatment (Kochakian \& Murlin, I935; Kruskemper, 1968) are reported in Table 4.

\section{Expt $\mathrm{I}$. Fractional synthetic rate of mixed tissue protein}

The results are recorded in Table 5 . The fractional synthetic rates in tissues from the placebotreated control rats were similar to previously published results (Waterlow \& Stephen, I968; Garlick, Millward \& James, 1975; Vernon \& Buttery, 1976). There were indications of an immediate reduction in the skeletal muscle fractional synthetic rate. The reduction was significant by days 7 and 14 after commencement of TBA treatment. The over-all reduction of $21.7 \%$ in the skeletal muscle fractional synthetic rate between days 7 and 14 was almost identical to the significant $2 \mathrm{I} \cdot 8 \%$ decrease we have previously reported after a $2 \mathrm{I}$ d injection period (Vernon \& Buttery, 1976). These decreases in skeletal muscle fractional synthetic rate after TBA treatment were less than that reported previously for myofibrillar catabolism (Vernon \& Buttery, 1978), an observation consistent with the increased growth rates of TBA treated rats reported here. Uterine fractional synthetic rate was significantly reduced I $4 \mathrm{~d}$ after the commencement of TBA treatment. There were no significant differences in the fractional synthetic rates of the liver and heart between the two groups.

The values for intracellular : extracellular free tyrosine specific activities of the placebotreated controls were similar to previously published results using L-[U-14 C] tyrosine (Garlick et al. 1975), except for the uterus where no results are available.

\section{Expt I. Skeletal muscle RNA,DNA and protein content}

The observed reduction in the skeletal muscle fractional synthetic rate after TBA treatment (Table 5) might have been expected to have been accompanied by a decrease in RNA 
Table 7. Expt $\mathrm{I}$. The effect of trenbolone acetate $(T B A)$ on skeletal muscle intracellular free amino acid concentration ( $\mu \mathrm{mol} / \mathrm{g}$ wet weight muscle) and plasma free tyrosine concentration $(\mu \mathrm{mol} / \mathrm{ml})$

(Mean values with their standard errors for six observations. On days I, 7 and I4 after the commencement of TBA treatment ( $800 \mu \mathrm{g} / \mathrm{kg}$ body-weight per d) the concentration of skeletal muscle intracellular and plasma amino acids were determined)

\begin{tabular}{|c|c|c|c|c|c|c|c|c|c|}
\hline \multirow[b]{3}{*}{ Day } & \multirow[b]{3}{*}{ Treatment } & \multicolumn{6}{|c|}{ Skeletal muscle intracellular amino acids } & & \\
\hline & & \multicolumn{2}{|c|}{ Glycine } & \multicolumn{2}{|c|}{ Tyrosine } & \multicolumn{2}{|c|}{ Lysine } & \multicolumn{2}{|c|}{ Arginine } \\
\hline & & Mean & SE & Mean & SE & Mean & SE & Mean & SE \\
\hline $\mathbf{I}$ & $\begin{array}{l}\text { TBA } \\
\text { Control }\end{array}$ & $\begin{array}{l}5.43 \\
2.87\end{array}$ & $\begin{array}{l}0.59^{*} \\
0.44 I\end{array}$ & $\begin{array}{l}0.084 \\
0.087\end{array}$ & $\begin{array}{l}0.009 \\
0.005\end{array}$ & $\begin{array}{l}0.98 \\
\mathrm{I} \cdot 82\end{array}$ & $\begin{array}{l}0.173^{* * *} \\
0.091\end{array}$ & $\begin{array}{l}0.23 \\
0.38\end{array}$ & $\begin{array}{l}0.063 \\
0.056\end{array}$ \\
\hline 7 & $\begin{array}{l}\text { TBA } \\
\text { Control }\end{array}$ & $\begin{array}{l}4 \cdot 49 \\
3 \cdot 39\end{array}$ & $\begin{array}{l}0.618 \\
0.213\end{array}$ & $\begin{array}{l}0.070 \\
0.074\end{array}$ & $\begin{array}{l}0.006 \\
0.006\end{array}$ & $\begin{array}{l}0.45 \\
I .11\end{array}$ & $\begin{array}{l}0.038^{* *} \\
0.119\end{array}$ & $\begin{array}{l}0.10 \\
0.25\end{array}$ & $\begin{array}{l}0.009^{* * *} \\
0.022\end{array}$ \\
\hline 14 & $\begin{array}{l}\text { TBA } \\
\text { Control }\end{array}$ & $\begin{array}{l}5 \cdot 06 \\
3 \cdot 75\end{array}$ & $\begin{array}{l}0.562 * \\
0.128\end{array}$ & $\begin{array}{l}0.076 \\
0.080\end{array}$ & $\begin{array}{l}0.005 \\
0.002\end{array}$ & $\begin{array}{l}0.58 \\
1.34\end{array}$ & $\begin{array}{l}0.76^{*} \\
0.222\end{array}$ & $\begin{array}{l}0.13 \\
0.24\end{array}$ & $\begin{array}{l}0.025^{*} \\
0.050\end{array}$ \\
\hline \multicolumn{10}{|c|}{ Plasma tyrosine } \\
\hline & Day $\ldots$ & & $\mathbf{I}$ & & 7 & & 14 & & \\
\hline & $\begin{array}{l}\text { TBA } \\
\text { Control }\end{array}$ & $\begin{array}{l}\text { Mean } \\
0.063 \\
0.060\end{array}$ & $\begin{array}{c}\text { SE } \\
0.004 \\
0.004\end{array}$ & $\begin{array}{r}\text { Mean } \\
0.065 \\
0.069\end{array}$ & $\begin{array}{c}\text { SE } \\
0.003 \\
0.004\end{array}$ & $\begin{array}{l}0.0 \\
0.0\end{array}$ & $\begin{array}{l}\tan \\
60 \\
62\end{array}$ & & \\
\hline
\end{tabular}

Statistical significance of differences between treatments: ${ }^{*} P<0.05,{ }^{* *} P<0.01,{ }^{* * *} P<0.001$.

For details, see p. 564 .

content because of their reported positive relationship (see, for example, Garlick et al. 1975). However, this was not the situation; TBA treatment resulted in a significant increase $(P<0.05)$ in skeletal muscle RNA I4 d after commencement of treatment (Table 6). The skeletal muscle RNA content of the TBA-treated rats $14 \mathrm{~d}$ after commencement of treatment was compared with that of non-injected entire male and female rats of a similar final body-weight (Table 5). The skeletal muscle RNA content of the TBA-treated female rats was significantly higher $(P<0.00 \mathrm{I})$ compared with that of the non-injected entire female rats.

The non-significant differences in skeletal muscle DNA and protein content between the two groups (Table 6) were assumed to indicate that hyperplasia and hypertrophy of the cells were not altered by TBA treatment.

\section{Expt $\mathrm{I}$. The concentration of amino acids in plasma and the skeletal muscle intracellular pool}

The concentrations of the following amino acids were measured in plasma and the intracellular fluid of skeletal muscle (aspartic acid, threonine, serine, proline, glycine, alanine, valine, methionine, isoleucine, leucine, tyrosine, phenylalanine, lysine, histidine and arginine) in TBA-treated rats and placebo-treated controls during Expt $I$. The only significant changes recorded (see Table 7) were in glycine, lysine and arginine. The skeletal muscle intracellular glycine concentration was significantly increased $(P<0.05)$ on day I and I 4 after commencement of treatment; there was also a non-significant $32.4 \%$ increase in glycine concentration on day 7 . The significance of these increases was not clear. However, a reduction in the skeletal muscle free lysine and arginine concentration was observed in the TBA-treated rats. Lysine and arginine concentrations were significantly reduced in the TBA-treated group after I and $7 \mathrm{~d}$ respectively, and these reductions were maintained to the end of the experimental period. 


\section{DISCUSSION}

During constant-infusion experiments, in the absence of measurement of the specific activity of the amino acyl-tRNA, it is conventional to consider the precursor specific activity to be equal to that of the total intracellular amino acid pool (Waterlow \& Stephen, 1968; Aub \& Waterlow, 1970; Fern \& Garlick, 1974). However, recently-published results have reported that the source of amino acids for hepatic protein synthesis fluctuates during the absorptive and postabsorptive state between the extracellular and intracellular pools respectively, and that the cellular membrane amino acid transport mechanism is an important intermediate in the initial steps of protein synthesis (Vidrich, Airhart, Bruno \& Khairallah 1977). Theoretically, calculated rates of protein synthesis based upon the specific activity of the intracellular precursor pool should be similar for different amino acids. Indeed, the placebo-treated control fractional synthetic rates reported here were similar to that of glycine/serine (Fern \& Garlick, 1974), tyrosine (Garlick et al. 1973; Millward et al. 1975; Millward et al. 1976) and lysine (Waterlow \& Stephen, 1968). Thus, the similarity of the plasma and skeletal muscle free tyrosine concentration (Table 7) and intracellular : extracellular pool specific activities of free tyrosine (Table 5) in the TBA-treated and control (placebo-treated) animals gave confidence that the measured reduction in skeletal muscle fractional synthetic rate after TBA treatment was unlikely to be due to the effects of the steroid on the amino acid pools, but rather reflect true changes in the synthetic rate. However, it must be acknowledged that it is not possible to rule out entirely the possibility that changes in amino acid pools do occur during TBA treatment and such changes may have frustrated attempts to obtain true fractional synthetic rates.

In the liver the catabolic rate appears to be the key control point, since the alteration in the protein content in response to different nutritional situations occurred with no change in the fractional synthetic rate and therefore must reflect changes in the rate of proteolysis (Garlick et al. 1973; Millward et al. 1976). It must be acknowledged that the use of the more simple equations of Waterlow \& Stephen (1968) rather than the more detailed approach of Garlick et al. (1973) may have resulted in a slight underestimation (about 10\%) of the liver fractional synthetic rates, however, both test and control livers would have been similarly affected.

In contrast with this apparently straightforward situation for the liver, it is not totally clear whether the rate of skeletal muscle protein synthesis or catabolism is the control point of growth (Millward, Garlick, James, Nnanyelugo \& Ryatt, 1973; Millward et al. 1975; Millward et al. 1976; Young \& Pluskal, 1977). The continued increase in the size of the liver after TBA treatment (Table 2) which was accompanied by no significant changes in either fractional synthetic rate or tissue water content (Tables 3 and 5) is consistent with the proposed catabolic control of liver size. A similar catabolic control of growth could be postulated for the heart after TBA treatment.

The reductions in muscle protein catabolism after TBA treatment (Vernon \& Buttery, 1976,1978 ) may have been a consequence of an induced decrease in the binding of glucocorticoids in skeletal muscle by trenbolone, the apparently active component of TBA (Pottier et al. 1975), which would reduce the glucocorticoid-dependent catabolism of muscle; androgens have been reported to displace glucocorticoids from their cytoplasmic muscle receptors both in vivo and in vitro (Mayer \& Rosen, 1975). The present results are consistent with the known effects of anabolic steroids on the catabolic effects of glucocorticoids on muscle protein metabolism (Kruskemper, I968). The proposed catabolic control of the size of the liver and heart after TBA treatment is consistent with the possible reduction in glucocorticoid-dependent muscle breakdown; glucocorticoid cytoplasmic receptors have been reported in various tissues (Baxter \& Forsham, 1972; Beato, Kalini \& Feigelson, 1972). 
Whether protein synthesis or protein catabolism or both controlled uterine size in the TBA-treated rats was not clear.

The reduction in the activity of RNA (Table 6) is consistent with the reduction in skeletal muscle fractional synthetic rate (Table 5) after TBA treatment. It is however interesting to note that a reduction in the growth rate of the rat has been observed to be associated with a reduction in the activity of RNA (Millward et al. 1975), a situation in direct contrast to the present findings. The decrease in skeletal muscle fractional synthetic rate and the increase in total carcass $\mathrm{N}$ reported here are consistent with our postulated reduction in energy expenditure during protein turnover and our reported increase in $\mathrm{N}$ retention of rats injected with TBA (Vernon \& Buttery, 1978).

A change in the rate of protein synthesis in response to amino acid supply has been demonstrated in a number of situations (see, for example, Morgan, Earl-Broadus, Wolpert, Geiger \& Jefferson, I971; Millward \& Garlick, 1972; Clemens \& Pain, I976). It could be postulated that the intracellular availability of lysine and arginine may be important for controlling protein synthesis in the TBA-treated rats (see, for example, Jefferson \& Korner, 1969; Morgan et al. I97I; Jefferson, Schworer \& Tolman, 1975).

Steroid hormones have been reported to increase the RNA content of stimulated tissues after the binding of the steroid to a cytoplasmic receptor and subsequent translocation of this complex to the nucleus (Jensen \& DeSombre, 1972; O'Malley \& Schrader, 1976). Testosterone has been reported to have a direct effect on skeletal muscle (see, for example, Gustafsson \& Pousette 1975; Dube, Lesage \& Tremblay, 1976). It is assumed that TBA in rat plasma is deacetylated to the apparently-active component trenbolone (Pottier et al. 1975). The direct effect of trenbolone on skeletal muscle appears feasible since the methylated derivative of trenbolone, I $7 \alpha$-methyl-trienolone (I $7 \beta$-hydroxy-I $7 \alpha$-methyl-oestra- 4,9 , I I-triene-3one), has been reported to bind efficiently to the skeletal muscle testosterone cytoplasmic receptor (Tremblay, Dube, Horkin \& Lesage, 1977) and androgen (testosterone) receptors have been isolated from skeletal muscle of both male and female rats (Dube et al. 1976). The previously reported binding of the skeletal muscle cytoplasmic receptor by $17 \alpha$-methyl-trienolone further supports the proposed reduction in glucocorticoiddependent muscle catabolism after TBA treatment.

We acknowledge the receipt of a Science Research Council Studentship for B.G.V; the support of the Agricultural Research Council and the gift of TBA from Roussel-Uclaf, France.

\section{REFERENCES}

Association of Official Agricultural Chemists (1970). Official Methods of Analysis, I I th ed. Washington DC: Association of Official Agricultural Chemists.

Atkin, G. E. \& Ferdinand, W. (1970). Analyt. Biochem. 38, 313 .

Aub, M. R. \& Waterlow, J. C. (1970). J. theor. Biol. 26, 243.

Baxter, J. D. \& Forsham, P. H. (1972). Am. J. Med. 53, 573.

Beato, M., Kalini, D. \& Feigelson, P. (1972). Biochem. biophys. Res. Commun. 47, 1464.

Burton, K. (1956). Biochem. J. 62, 315.

Chan, K. H., Heitzman, R. J. \& Kitchenham, B. A. (1975). Br. vet. J. 131, 170.

Clemens, M. J. \& Pain, V. M. (1976). In Protein Metabolism and Nutrition, p. 19 [D. J. A. Cole, K. N. Boorman, P. J. Buttery, D. Lewis, R. J. Neale and H. Swan, editors]. London: Butterworths.

Dube, J. Y., Lesage, R. \& Tremblay, R. R. (1976), Can.J. Biochem. Physiol. 54, 50.

Fern, E. B. \& Garlick, P. J. (1974). Biochem. J. I42 413.

Garlick, P. J., Millward, D. J. \& James, W. P. T. (1973). Biochem. J. 136, 935.

Garlick, P. J., Millward, D. J., James, W. P. T. \& Waterlow, J. C. (1975). Biochim. biophys. Acta 414, 71.

Goldberg, A. L. (1969a). J. biol. Chem. 244, 3217.

Goldberg, A. L. (1969b). J. biol. Chem. 244, 3223.

Goldberg, A. L. \& Dice, J. F. (1974). A. Rev. Biochem. 43, 835.

Goldberg, A. L., Howell, E. M., Li, J. B., Martel, S. B. \& Prouty, W. F. (1974). Fedn Proc. Fedn Am. Socs exp. Biol. 33, I I 12 . 
Gustafsson, J-A. \& Pousette, A. (I975). Biochemistry, Easton 14, 3094.

Hider, R. C., Fern, E. B. \& London, D. R. (1971). Biochem. J. r2r, 817.

Jefferson, L. S. \& Korner, A. (1969). Biochem. J. III, 703.

Jefferson, L. S., Schworer, C. M. \& Tolman, E. L. (1975). J biol. Chem. 250, 197.

Jensen, E. V. \& DeSombre, E. R. (1972). A. Rev. Biochem. 41, 203.

Kerr, S. E. \& Seraidorian, K. (1945). J. biol. Chem. 159, 2 I I.

Kochakian, C. D. \& Murlin, J. R. (1935). J. Nutr. 10, 437.

Kruskemper, H. L. (1968). In Anabolic Steroids, [translated by C. H. Doering]. London: Academic Press.

Lowry, O. H, Rosebrough, N. J., Farr, A. L. \& Randall, R. J. (I951). J. biol. Chem. 193, 265.

Manchester, K. L. (1976). In Protein Metabolism and Nutrition, p. 35 [D. J. A. Cole, K. N. Boorman, P. J.

Buttery, D. Lewis, R. J. Neale and H. Swan, editors]. London: Butterworths.

Mayer, M. \& Rosen, F. (1975). Am. J. Physiol. 229, I38I.

Millward, D. J. \& Garlick, P. J. (1972). Proc. Nutr. Soc. 31, 257.

Millward, D. J., Garlick, P. J., James, W. P. T., Nnanyelugo, D. O. \& Ryatt, J. S. (I973). Nature, Lond. 241, 204.

Millward, D. J., Garlick, P. J., Nnanyelugo, D. O. \& Waterlow, J. C. (1976). Biochem. J. r56, I85.

Millward, D. J., Garlick, P. J., Stewart, R. J. C., Nnanyelugo, D. O. \& Waterlow, J. C. (I975). Biochem. J. r50, 235.

Morgan, H. E., Eari-Broadus, A., Wolpert, E. B., Geiger, K. E. \& Jefferson, L. S. (1971). J. biol. Chem. 246, 2152 .

Mueller, E. E. (1974). In Physiology 1, vol. 5, Endocrine Physiology, p. I4I [S. M. McCann, editor]. London: Butterworths.

Munro, H. N. \& Fleck, A. (I969). In Mammalian Protein Metabolism vol. 3, p. 424 [H. N. Munro, editor]. New York: Academic Press.

O’Malley, B. \& Schrader, W. T. (1976). Scient. Am. 234, 32.

Pottier, J., Busigny, M. \& Grandadam, J. A. (1975). J. Anim. Sci. 41, 962.

Preston, R. L. (1975). J. Anim. Sci. 4I, 1414.

Scharff, R. \& Wool, I. G. (1965). Biochem.J. 97, 257.

Schimke, R. T. \& Doyle, D. (1970). A Rev. Biochem. 39, 929.

Stein, W. H. \& Moore, S. (1954). J. biol. Chem. 2II, 915.

Tremblay, R. R., Dube, J. Y., Horkim, M. A. \& Lesage, R. (1977). Steroids 29, I85.

Vernon, B. G. \& Buttery, P. J. (1976). Br.J. Nutr. 36, 575.

Vernon, B. G. \& Buttery, P. J. (I978). Anim. Prod. (In the Press).

Vidrich, A., Airhart, J., Bruno, M. K. \& Khairallah, E. A. (1977). Biochem. J. 162, 257.

Waterlow, J. C. \& Stephen, J. M. L. (1968). Clin. Sci. 33, 489.

Young, V. R. \& Pluskal, M. G. (1977). Proc. 2nd int. Symp. Protein Metabolism and Nutrition, The Netherlands, p. 17 . 